\title{
Fuori luogo. Contatti uditivi tra Ottocento e Novecento
}

\author{
Edoardo Dotto
}

Abstract

In piena analogia con le tecnologie che, soprattutto nell'ultimo anno, hanno consentito alle nostre comunicazioni personali di svilupparsi attraverso una sorta di telepresenza virtuale, tra il XIX e il XX secolo in Francia si sono diffusi alcuni dispositivi per la comunicazione a distanza dei suoni e della voce che, da principio, hanno creato clamore e smarrimento, presto sostituiti da un'estesa condivisione e accettazione sociale.

Si prendono qui in considerazione - anche attraverso l'esperienza di Marcel Proust - due di queste desuete tecnologie, il telefono e il théâtrophone, cercando di mostrare come lo stupore che questi mezzi suscitavano si annidasse nello scollamento reciproco tra la collocazione fisica dell'uditore e quella dell'interlocutore, nel loro essere, letteralmente, 'fuori luogo'. Questa condizione può essere accostata a quella che si determina ogni qual volta utilizziamo uno strumento, persino un utensile, per percepire e agire superando i confini mensurali del nostro corpo, utilizzando sintesi drastiche nelle informazioni che veicoliamo, in affinità ai fondamenti costitutivi di ogni forma di rappresentazione.

Parole chiave

théâtrophone, telefono, Marcel Proust, telepresenza, audio.

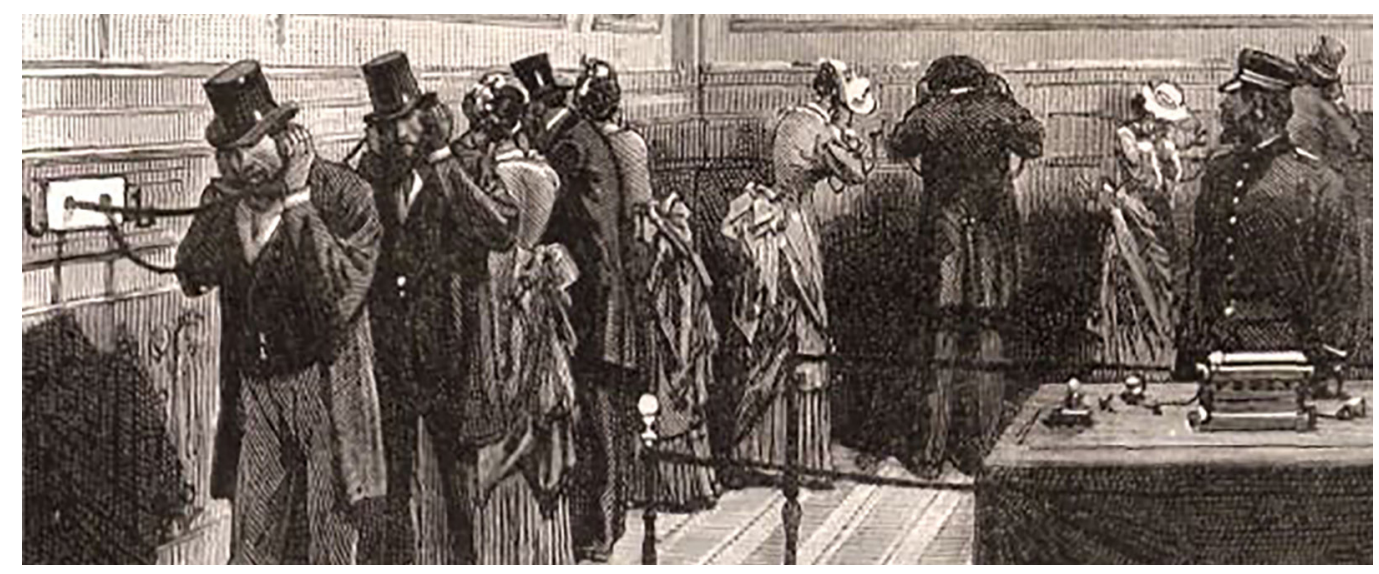




\section{Introduzione}

Ogni qual volta la tecnologia ha reso possibile vedere, udire, spostare qualcosa da lontano - e ancor di più quando ciò è avvenuto in modo biunivoco e interattivo - il nostro raggio personale di azione si è esteso fattivamente e, dopo un immancabile periodo di smarrimento, la nuova condizione si è trasformata in una modalità consueta, usuale, pienamente accettata, spesso priva dell'inquietante appeal di cui poteva essere ammantata in principio. Se è vero che, come scriveva Maldonado già nel 1992, "le realtà virtuali [...] spezzano il nostro legame con il mondo delle cose e dei corpi, assottigliano sempre di più la nostra possibilità di esperienza con l'universo della fisicità", non possiamo in alcun modo dimenticare che comunque "questi costrutti iconici sono stati elaborati sulla base della nostra esperienza passata e presente con quel mondo e con quell'universo", e che quindi si nutrono delle nostre esperienze compiute nell'ambito consolidato della nostra realtà [Maldonado 1992, p. 67]. Allo stesso modo dei "costrutti iconici", il cui raggio di azione si annida nel campo del visibile, ciò avviene analogamente nel dominio delle comunicazioni e delle rappresentazioni in ambito esclusivamente uditivo, quelle in cui a essere impegnato è soltanto - o comunque principalmente - il canale capace di trasferire a distanza voci e suoni.

In questa brevissima nota si vogliono prendere in considerazione alcune modalità di comunicazione che, a cavallo tra il $X I X$ e il $X X$, secolo si affidavano esclusivamente alla trasmissione dei suoni sfruttando le emergenti tecnologie telefoniche. Con l'intento esclusivo di presentare alcuni casi emblematici distanti dalla nostra storia recente - e forse per questo ancor più adatti per considerare gli effetti delle modalità di comunicazione più attuali - si prenderà in considerazione il Théâtrophone, una tecnica di trasmissione degli spettacoli teatrali che si diffuse a Parigi a partire dagli anni Ottanta del XIX secolo, e si farà riferimento alle riflessioni di Marcel Proust sullo smarrimento che simili applicazioni - persino il semplice utilizzo del telefono - possono generare al loro apparire.

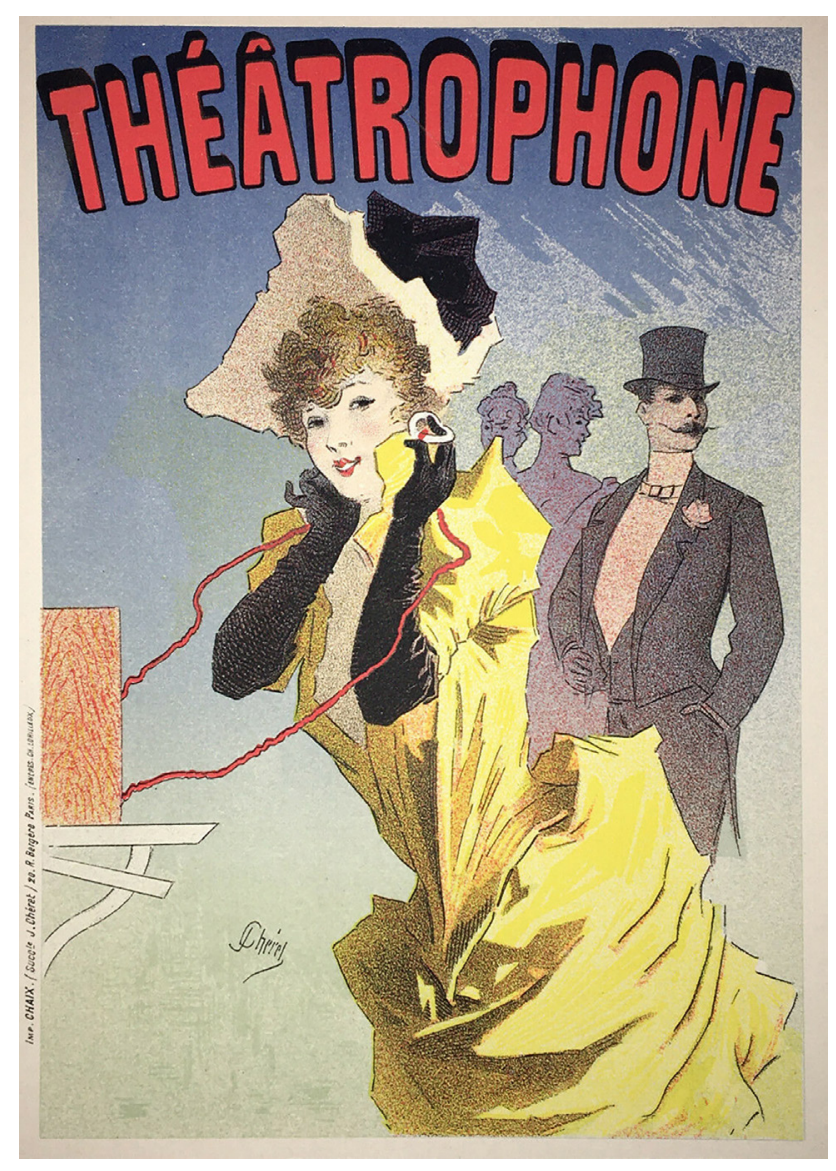




\section{II teatro, da lontano}

Tra l'agosto e il novembre del 188 I presso il Palais de l'Industrie di Parigi si tenne la prima Esposizione Internazionale dell'Energia Elettrica. In quegli anni le applicazioni rivoluzionarie dell'elettricità si susseguivano, promettendo profitti e inedite comodità, lasciandosi dietro una scia di stupore. I visitatori poterono vedere in anteprima invenzioni come la dinamo di Gramme, la luce a incandescenza, vari modelli di reti di distribuzione dell'energia, il nuovo modello di telefono inventato da Graham Bell e il Théâtrophone (fig. I). Quest'ultimo dispositivo, proposto dall'ingegnere Clément Ader, inventore di nuove macchine volanti e costruttore nel 1879 della prima rete telefonica parigina, consentiva di ascoltare gli spettacoli teatrali - opere liriche, operette, concerti - in tempo reale, restando lontani dalla sala teatrale, collegati da cavi elettrici che, al pari della rete telefonica, riuscivano a portare i suoni a distanza, fuori dalla loro collocazione naturale. Alcuni microfoni installati direttamente sul palcoscenico del teatro dell'Opéra e della Comédie-française portavano attraverso dei cavi sotterranei i suoni e le voci degli spettacoli direttamente all'interno del Palazzo dell'Industria. Anche l'Eliseo fu collegato e - addirittura - il Presidente della Repubblica Jules Grévy inaugurò la prima sessione di ascolto. Questa invenzione, finanziata dalla Société générale des téléphones ebbe un enorme successo e Ader, dopo avere vinto la medaglia d'oro dell'esposizione, ricevette persino la legion d'onore [Van Drie 20 I 5, pp. 10 e sgg.].

Già in quegli anni erano stati realizzati altri sistemi per la trasmissione delle performance teatrali a distanza ma l'invenzione di Ader offriva una qualità sino allora mai raggiunta, dando agli utenti l'illusione di trovarsi - tenendo gli occhi chiusi - all'interno della sala teatrale. La peculiarità dell'invenzione di Ader consisteva nell'utilizzare una coppia di microfoni, disposti ai lati del palcoscenico, ciascuno dei quali trasmetteva il suono a un solo orecchio dell'ascoltatore. In questa maniera il differente volume e il lieve ritardo tra i due canali contribuivano a far nascere una sensazione di piena verosimiglianza con l'ascolto in presenza. In altri termini, la particolarità del Théâtrophone era quello di essere un dispositivo binaurale, il primo a porre le basi per la cosiddetta 'stereofonia'. Al pari dei cosiddetti 'anaglifi', le immagini che andavano guardate indossando occhiali con vetri rossi e blu per cogliere la sensazione della tridimensionalità inventate qualche decennio prima da Wilhelm Rollman [Dotto,Vinci 2009, pp. I4, I5], la tecnica di Ader sfruttava le acquisizioni della più moderna fisiologia umana per suscitare virtualmente la sensazione della realtà.

Nel corso dell'Esposizione, gli spettatori affollavano la sala di ascolto del Palazzo e seguivano l'opera indossando alcuni dispositivi acustici appesi alla parete (fig. 2), una modalità del tutto inedita, intima, personale che, pur all'interno di una sala affollata, favoriva l'isolamento di cia-

Fig. 2. La sala di ascolto del Théâtrophone al Palais de l'Industrie Parigi, da Le Magasin pittoresque, 1882, p. 93.

Fig. 3. Apparecchio pubblico per il

Théâtrophone, da D. L. Montillot, Le téléphone pratique, Paris, A. Grelot, pratique, Paris,
1893, p. 465.

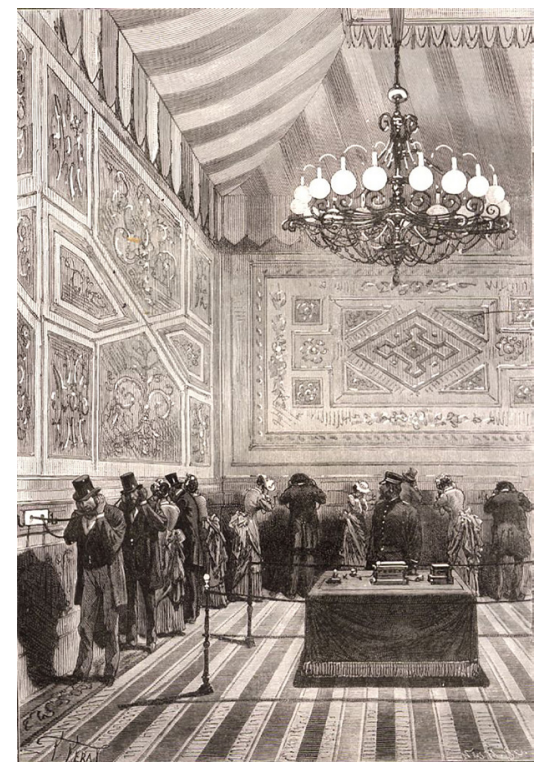

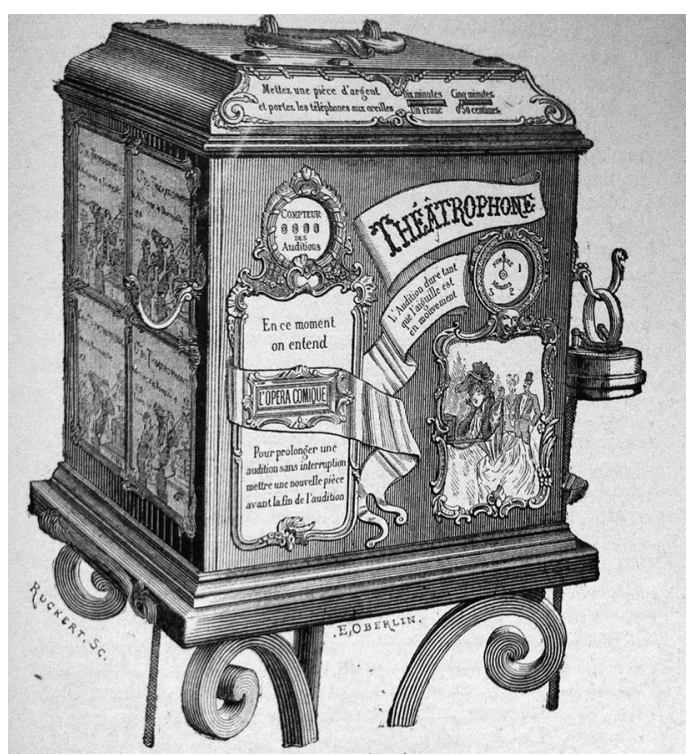


scun uditore. Su un giornale del tempo si commentava: "non appena portati i due ricevitori telefonici alle orecchie, sembrava che all'improvviso fossimo trasportati sul palcoscenico dell'Opéra. Chiudendo gli occhi, l'illusione era completa, pensavamo di essere testimoni della rappresentazione stessa, di sentire cantare Lasalle o l'illustre Krauss, ascoltando gli accordi orchestrali e gli applausi del pubblico" Van Drie 20 15, p. 19].

L'invenzione di Ader non ebbe alcun immediato successo commerciale ma alcuni anni dopo, all'esposizione Universale di Parigi del 1889, venne presentato un modello portatile (fig. 3) delThéâtrophone che consentì una diffusione presso sale di ascolto dedicate e perfino nelle abitazioni private (Fig. 4). A partire dal I 890 furono proposti agli utenti degli abbonamenti al servizio che consentivano una scelta tra vari concerti, opere liriche e rappresentazioni di altro genere. Vennero diffusi dei programmi quotidiani e dal 1893 furono montati gli apparecchi utilizzati all'Esposizione del I88I in una sala del Museo Grevin dove gli utenti potevano ascoltare persino spettacoli di varietà. II Théâtrophone divenne un mezzo di intrattenimento che si integrava pienamente con il flusso ininterrotto delle serate parigine, da quelle in società a quelle più intime e riservate, e aprì la strada a nuove modalità di fruizione della musica e dello spettacolo che andarono conquistando sempre più campo, finché nel 1936, in seguito all'evoluzione dei fonografi e alla diffusione della radio, la società che gestiva il servizio, già in affanno da alcuni anni, si ritirò dagli affari.

Fig. 4. Serata di ascolto al Théâtrophone, 1892 $<$ https://alpoma.net/
end (consultato il 20 marzo 2021)

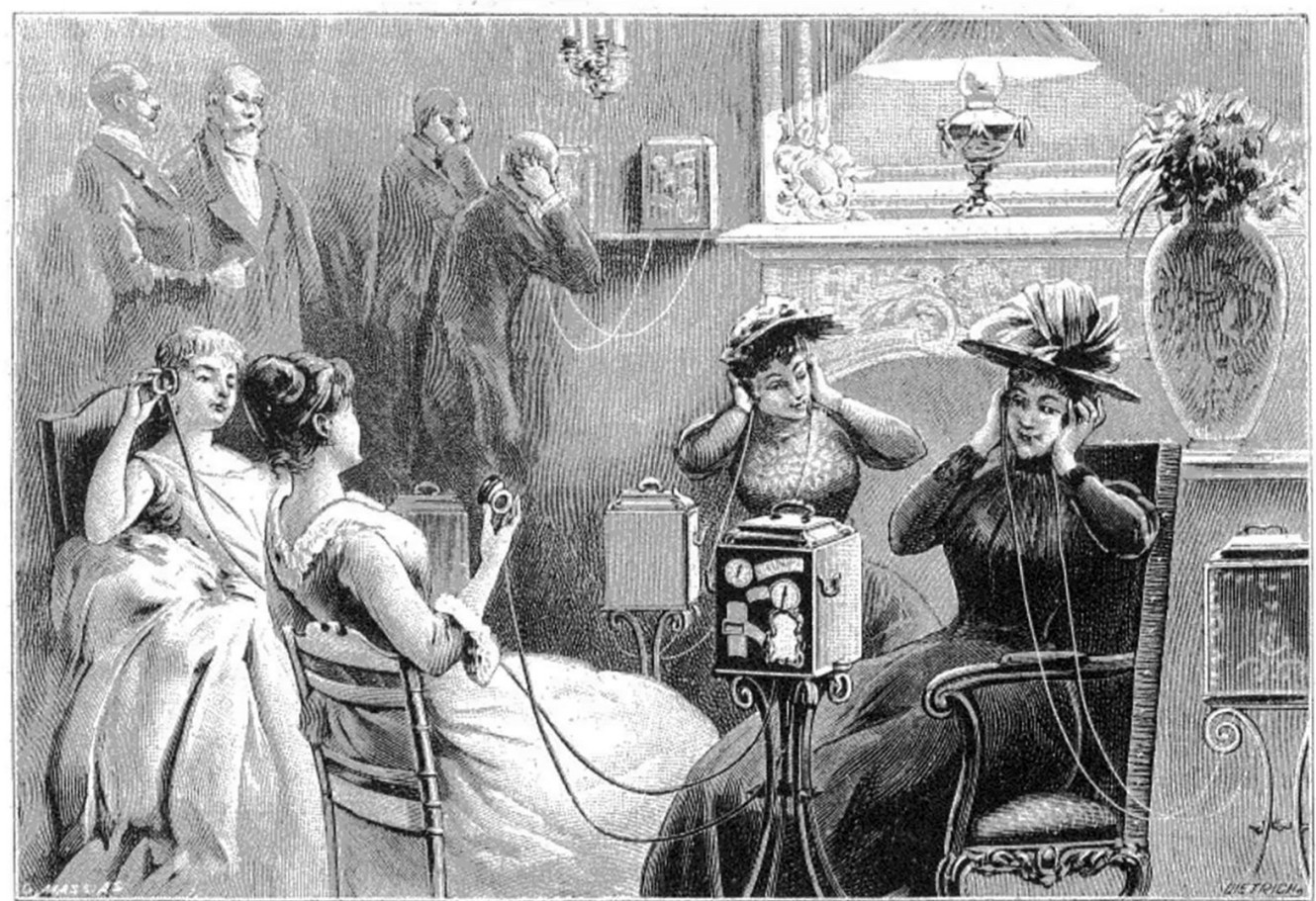

\section{Marcel Proust e il telefono}

Tra gli utenti abbonati al servizio del Théâtrophone figura a partire dal I9 I I anche Marcel Proust. In quell'anno lo scrittore compiva quarant'anni ed era profondamente immerso nella scrittura della sua opera più famosa, la Recherche, che sarebbe stata pubblicata a partire dal 19|3. Come è noto, Proust non usciva volentieri da casa, anche a causa della sua salute cagionevole e del suo carattere riservato. IIThéâtrophone costituiva per lui un modo di tenersi aggiornato sugli spettacoli della città e di 'farsi compagnia' nel corso delle lunghe sessioni di lavoro. 
L'uso delle tecnologie telefoniche - e dello smarrimento che esse potevano generare - è oggetto di una intensa riflessione inserita nel terzo volume della sua opera, La parte di Guermantes, pubblicata nel 1921, in cui il protagonista del romanzo, che si è soliti identificare con lo stesso Proust, circa ventenne - quindi all'inizio degli anni Novanta dell'Ottocento - si reca nel piccolo paese di Doncières in visita a un amico fraterno che lì svolge il servizio militare. Durante la sua permanenza si trova a comunicare, oltre che per lettera, anche per telefono con l'amata nonna materna, la quale costituiva per lui un riferimento emotivo imprescindibile. Per potere effettuare la telefonata, deve recarsi presso l'ufficio delle Poste, dove l'attende l'appuntamento telefonico. La lungaggine dell'attesa lo stizzisce, nonostante quell'incontro possa fargli godere - scrive Proust - della "meravigliosa fantasmagoria cui bastano pochi istanti per far comparire accanto a noi, invisibile ma presente, la persona con la quale vogliamo parlare e che, senza muoversi dal suo tavolo, nella città dove vive [...] sotto un cielo diverso dal nostro, con un tempo che non è necessariamente lo stesso, fra circostanze e preoccupazioni che noi ignoriamo e di cui ci parlerà, si trova di colpo trasportata (lei, e tutto l'ambiente dove continua a essere immersa) a centinaia di leghe di distanza, accanto al nostro orecchio, nel momento esatto stabilito dal nostro capriccio", tale - continua Proust più avanti - da farci sembrare "simili al personaggio del racconto al quale una maga, esaudendone il desiderio, fa apparire in una luce sovrannaturale la nonna o la fidanzata in atto di sfogliare un libro, di versare lacrime, di cogliere fiori, vicinissima allo spettatore e tuttavia Iontanissima, nel luogo medesimo dove si trova realmente" [Proust 1995, pp. I32, I33].

Proust avverte e subisce il gravame emotivo di quest'ossimoro, dell'inquietante simultaneità di lontananza e vicinanza, separazione e presenza. La voce della parente udita a Donciéres è - tragicamente e letteralmente - 'fuori luogo'. Questa consapevolezza costituisce un motivo di confusione, di smarrimento, di tristezza e diventa perfino il presagio, più che di un futuro riavvicinamento, di una separazione eterna. II peso della incolmabile distanza tra i due interlocutori porta il protagonista - Marcel - a scappare da Doncières, a tornare rapidamente a Parigi per rivedere la nonna. La voce familiare della parente, udita mille volte, continua Proust “... l'ascoltavo oggi per la prima volta. E siccome m'appariva mutata nelle sue proporzioni dall'istante in cui era diventata un tutto e giungeva a me così sola e senza l'accompagnamento dei tratti del volto, scopersi quanto fosse dolce quella voce" [Proust 1995, p. 134].

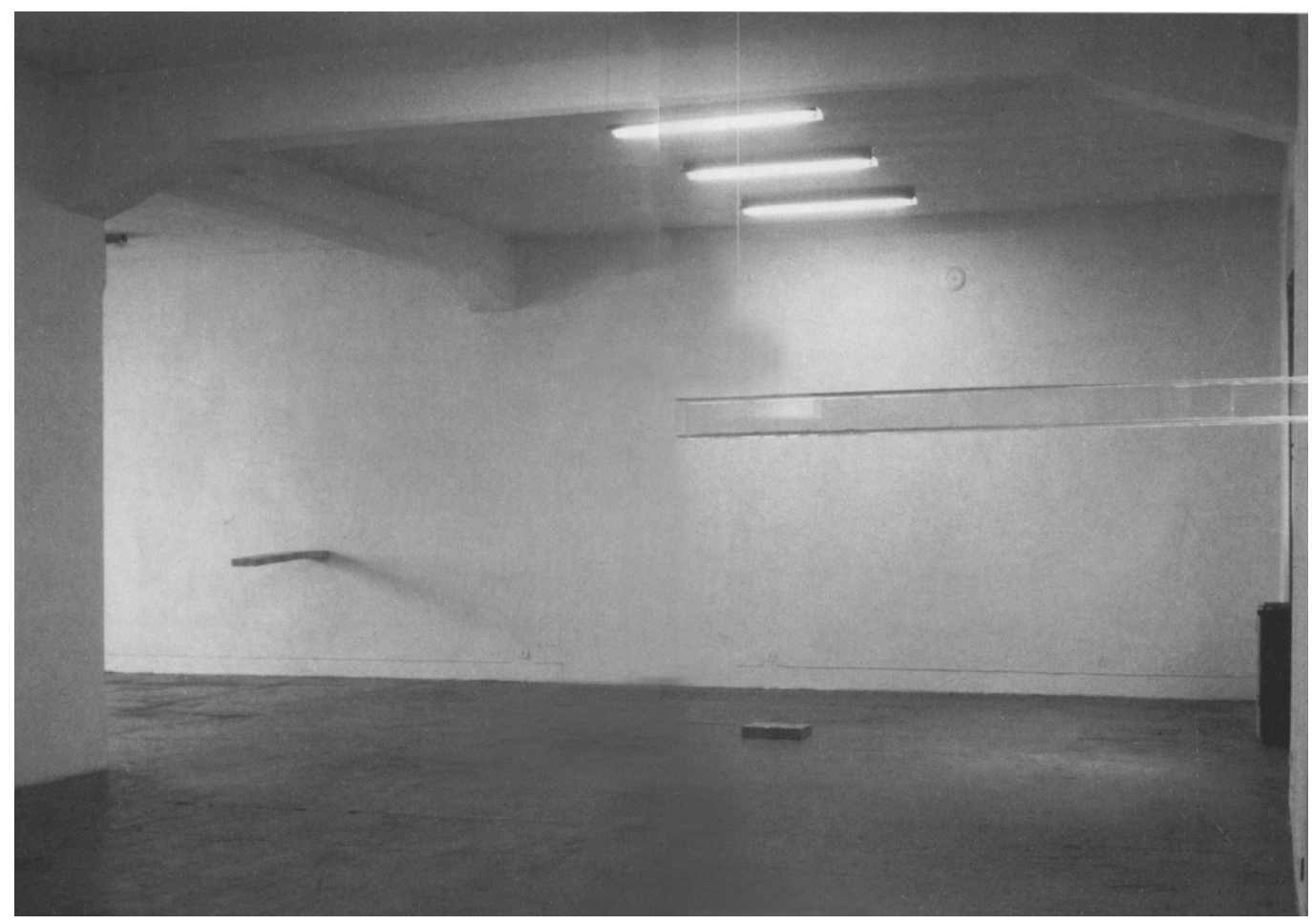




\section{Fuori luogo}

Il giovane Marcel che da ragazzo si dibatte in queste riflessioni angosciose non è lo stesso che da adulto maturo usa con disinvoltura i mezzi di comunicazione a sua disposizione e che si serve del Théâtrophone per portare virtualmente la sua presenza fuori dalle mura di casa. D'altra parte, è lui stesso a notare come "l'abitudine fa così presto a spogliare del loro mistero le forze sacre con cui siamo messi in contatto" [Proust 1995, p. I32]. II suo smarrimento si muta facilmente in consuetudine, lo stupore tende a essere assorbito dalla continuità e - come tutti sperimentiamo quotidianamente - dopo un iniziale sbandamento, generalmente queste tecnologie diventano degli efficaci sostituti della nostra presenza fisica. Probabilmente questa confusione iniziale dipende dal fatto che tendiamo a inquadrare le nostre esperienze in relazione al luogo specifico in cui esse si compiono. Per restare nel campo delle esperienze legate all'uso dell'udito, è utile considerare un'opera di Giuseppe Penone realizzata alla fine degli anni Sessanta [Penone 1977, pp. 56, 59]. L'artista costruisce un raffinato dispositivo capace di generare una sottile forma di smarrimento. All'interno di una stanza, sfruttando un piccolo condotto in plexiglass collegato alla finestra (fig. 5), riesce a portare i suoni che si sarebbero uditi provenire dall'esterno, se la finestra fosse stata aperta, fino al centro del locale. Quei suoni ci sono familiari, come anche l'ambiente in cui ci troviamo (una stanza del tutto ordinaria) eppure in modo sottile, puntuale e profondo viviamo un turbamento dovuto al fatto che i suoni che udiamo sono distanti da dove dovrebbero essere, fuori dal loro luogo di elezione. Allo stesso modo della voce della nonna a Doncières o dei volti dei nostri colleghi di lavoro che campeggiano nell'intimità della nostra stanza durante una videoconferenza, il sovvertimento costruito da Penone è fonte di uno stato di sorpresa e di emozione.

Fig. 6. Saul Steinberg, uNow inhale deeply. Mrs. Saunders»), 1945

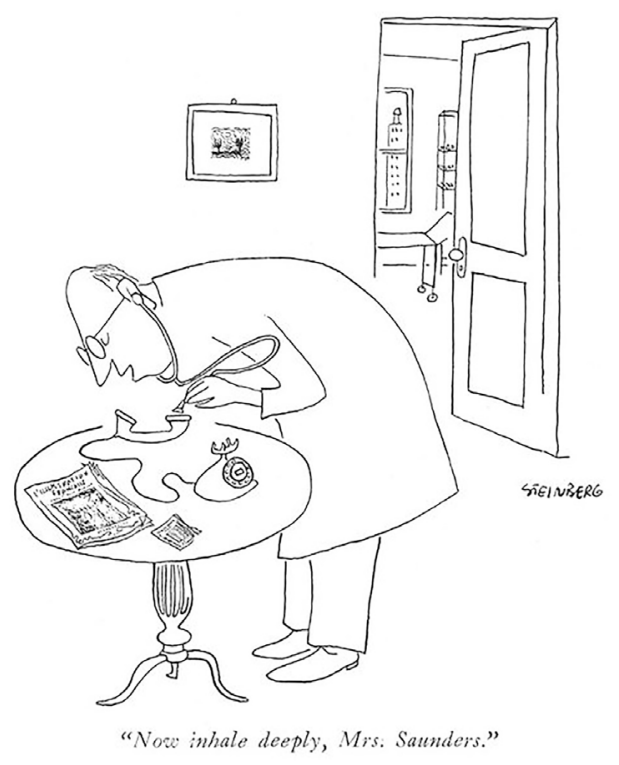

\section{Conclusione}

Una vignetta di Saul Steinberg degli anni Quaranta (fig. 6), quando la moderna telemedicina costituiva ancora una frontiera inaccessibile, insinuava con ironia la possibilità che i consueti strumenti del comunicare potessero già allora aprire nuove possibilità [Steinberg 1945]. In fondo, a ben vedere, utilizziamo queste tecnologie per accedere a luoghi lontani esattamente come se usassimo degli utensili, delle protesi, delle estensioni temporanee del nostro corpo, la cui misura, i cui labili confini si estendono plasticamente, spesso senza che ne abbiamo piena consapevolezza. Gregory Bateson chiarisce questo aspetto con un esempio 
particolarmente efficace: "Supponiamo che io sia cieco e che usi un bastone e vada a tentoni. In quale punto comincio io? II mio sistema mentale finisce all'impugnatura del bastone? $\bigcirc$ finisce con la mia epidermide? Comincia a metà del bastone? $\bigcirc$ alla punta del bastone? Tutte queste sono domande senza senso. II bastone è come un canale lungo il quale vengono trasmesse trasformate di differenze" [Bateson 1976, p. 500]. Allo stesso modo nei nostri collegamenti, telefonici, in videoconferenza o di altro genere, estendiamo la nostra presenza, temporaneamente. Come aggiunge Bateson - "... quando il cieco si siede per mangiare, il bastone e i suoi messaggi non saranno più pertinenti" - quando spegniamo il videoterminale rientriamo, almeno temporaneamente, in una diversa dimensione corporale, più prossima a quella definita dai confini della nostra forma.

I dispositivi di cui si è detto, se riguardati dal punto di vista focalizzato da Bateson, si connotano pienamente come degli strumenti, in grado di metterci in contatto con luoghi lontani. Questa comunicazione awiene attraverso canali specifici - quello tattile per il bastone di Bateson o quello uditivo per il Théâtrophone - ciascuno dei quali costituisce una sintesi apodittica della realtà con cui interagiamo, la stessa sintesi funzionale che sostanzia ogni forma di rappresentazione la cui efficacia si dipana soltanto grazie alla scelta e all'utilizzo delle informazioni strettamente indispensabili.

Le modalità che appartengono ai due esempi presi rapidamente in considerazione in queste pagine, il Théâtrophone e il telefono, nonostante le enormi differenze con le complesse modalità visuali - sicuramente più adeguate ai nostri tempi e più consone ai nostri interessi di studio - intrattengono comunque con esse delle enormi analogie e sembrano condividerne profondamente i concetti cardine cui fare riferimento, quello di strumento e quello di rappresentazione.

\section{Riferimenti bibliografici}

Bateson G. (1976). Verso un'ecologia della mente. Milano:Adelphi. [ed. origin. Steps to an Ecology of Mind, San Francisco: Chandler Publishing Company, 1972].

Dotto E., Vinci F. (2009). Gli anaglifi geometrici. Storia e costruzione grafica. Siracusa: Lombardi.

Maldonado T. (1992). Reale e virtuale. Milano: Feltrinelli.

Penone G. (1977). Rovesciare gli occhi. Torino: Einaudi.

Pisano G. (2012). The Théâtrophone, an Anachronistic Hybrid Experiment or One of the First Immobile Traveler Devices? In: A. Gaudreault, N. Dulac, S. Hidalgo (a cura di). A Companion to Early Cinema, pp. 80-98. Pasig:Wiley and sons -Blackwell Pub.

Proust M. (1995). Alla ricerca del tempo perduto - III. La parte di Guermantes. Milano: Mondadori. [ed. origin. Le Côté de Guermantes. Paris: Gallimard, 1921 ]

Sakamoto H. (2006). Du théâtrophone au téléphone repenser la «mise en scène» du dialogue dans «à la recherche du temps perdu". In R. Goedendorp et al. (Eds.). Marcel Proust Aujourd'hui, vol. 4, Proust et le théâtre, pp. 25I-27I.

Steinberg S. (1945). All in line. New York: Penguin Book.

Van Drie M. (2015). L'espace scénique du théâtrophone (I88I-1930) et la figure nouvelle du spectateur auditeur. In Modèles et modalités de la transmission Culturelle, pp. 4 I -68. Paris: Éditions de la Sorbonne.

Van Drie M. (2016). Hearing through the théâtrophone: Sonically constructed spaces and embodied listening in the late nineteenth-century French theatre. In SoundEffects - An Interdisciplinary Journal of Sound and Sound Experience, 5(I), pp. 73-90.

\footnotetext{
Autore

Edoardo Dotto, Università di Catania, edoardo.dotto@unict.it

Per citare questo capitolo: Dotto Edoardo (2021). Fuori luogo. Contatti uditivi tra Ottocento e Novecento/Out of place. Auditory contacts between the nineteenth and twentieth centuries. In Arena A., Arena M., Mediati D., Raffa P. (a cura di). Connettere. Un disegno per annodare e tessere. Linguaggi Distanze Tecnologie. Atti del $42^{\circ}$ Convegno Internazionale dei Docenti delle Discipline della Rappresentazione/Connecting. Drawing for weaving relationship. Languages Distances Technologies. Proceedings of the $42^{\text {th }}$ International Conference of Representation Disciplines Teachers. Milano: FrancoAngeli, pp. $1601-1614$.
} 


\title{
Out of Place. Auditory Contacts between the Nineteenth and Twentieth Centuries
}

\author{
Edoardo Dotto
}

Abstract

In full analogy with the technologies that, especially in the last year, have allowed our personal communications to develop through a sort of virtual telepresence, between the nineteenth and twentieth centuries in France some devices for the remote communication of sounds and voice spread. They, at the beginning, created clamor and bewilderment, soon replaced by extensive sharing and social acceptance. Two of these obsolete technologies, the telephone and the Théatrophone, are taken into consideration here -also through the experience of Marcel Proust- trying to show how the amazement that these means aroused was nestled in the mutual disconnect between the physical location of the listener and that of the interlocutor, in their being, literally, 'out of place'. This condition can be compared to the one that is determined every time we use an instrument, even a tool, to perceive and act by overcoming the mensural boundaries of our body, using drastic syntheses in the information we convey, in affinity to the constitutive foundations of every form of representation.

Keywords

Théâtrophone, Telephone, Marcel Proust, telepresence, audio.

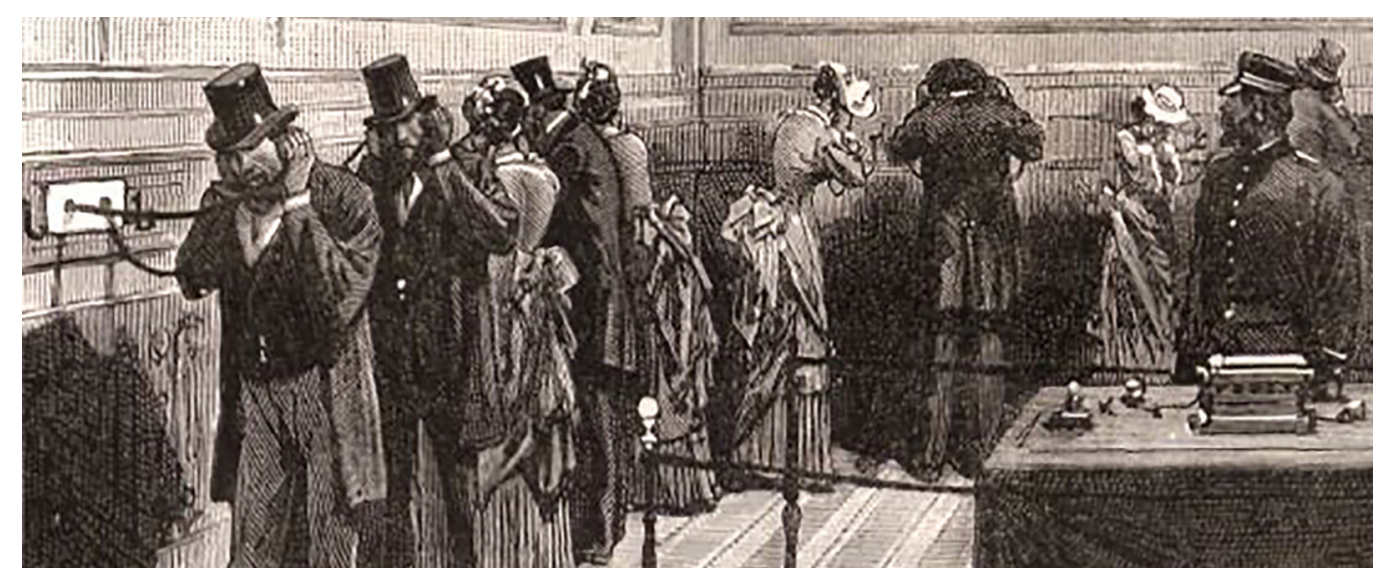




\section{Introduction}

Whenever technology has made it possible to see, hear, move something from afar -and even more so when this happened in a two-way and interactive way- our personal range of action has been effectively extended and, after an inevitable period of bewilderment, the new condition has been transformed into a customary, usual, fully accepted modality, often devoid of the disturbing appeal it could have been cloaked in in the beginning. If it is true that, as Maldonado wrote in 1992, "virtual realities [...] break our bond with the world of things and bodies, they increasingly reduce our possibility of experience with the universe of physicality", we can in no way forget that however "these iconic constructs have been elaborated on the basis of our past and present experience with that world and with that universe", and that therefore they feed on our experiences made in the consolidated context of our reality [Maldonado 1992, p. 67].

In the same way as the "iconic constructs", whose range of action is nestled in the visible field, this happens similarly in the domain of communications and representations in the purely auditory sphere, those in which only -or at least mainly- the channel capable of remotely transferring voices and sounds. In this very brief note some modes of communication are considered that, at the turn of the nineteenth and twentieth centuries, relied exclusively on the transmission of sounds by exploiting the emerging telephone technologies. With the exclusive intention of presenting some emblematic cases distant from our recent history -and perhaps for this reason even more suitable for considering the effects of the most current communication methods- we will consider the Théâtrophone, a transmission technique of theatrical performances that is widespread in Paris since the 1880s, and reference will be made to Marcel Proust's reflections on the bewilderment that similar applications - even the simple use of the telephone- can generate when they appear.

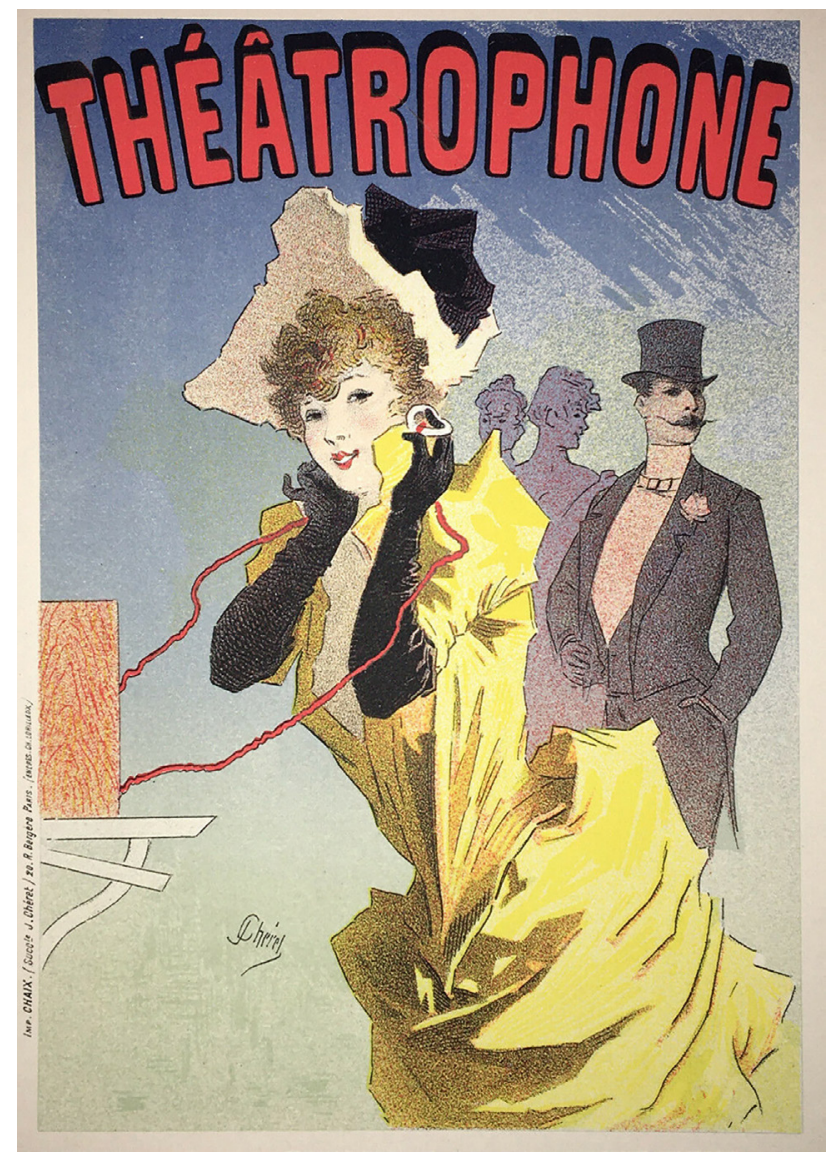




\section{The theater, from afar}

Between August and November I88I, the first International Exhibition of Electricity was held at the Palais de l'Industrie in Paris. In those years, the revolutionary applications of electricity followed one another, promising profits and unprecedented comforts, leaving behind a trail of amazement. Visitors were able to preview inventions such as the Gramme dynamo, incandescent light, various models of energy distribution networks, the new telephone model invented by Graham Bell and the Théâtrophone (fig. I). This last device, proposed by the engineer Clément Ader, inventor of new flying machines and builder of the first Parisian telephone network in 1879, made it possible to listen to theatrical performances -operas, operettas, concerts- in real time, while staying away from the theater, connected by electric cables which, like the telephone network, were able to carry sounds at a distance, out of their natural location. Some microphones installed directly on the stage of the Opéra and Comédie-française theaters carried the sounds and voices of the shows directly into the Palace of Industry through underground cables. The Elysée was also connected and -even- the President of the Republic Jules Grévy inaugurated the first listening session. This invention, financed by the Société générale des telephones, was a huge success and Ader, after winning the gold medal of the exhibition, even received the legion of honor [Van Drie 2015, pp. 10 and sgs. ]. Already in those years other systems for the remote transmission of theatrical performances had been created but Ader's invention offered a quality never before achieved, giving users the illusion of being -keeping their eyes closed-inside the theatre. The peculiarity of Ader's invention consisted in using a pair of microphones, arranged on the sides of the stage, each of which transmitted the sound to only one ear of the listener. In this way, the different volume and the slight delay between the two channels helped to create a feeling of full likelihood with listening in presence. In other words, the peculiarity of the Théâtrophone was that it was a binaural device, the first to lay the foundations for the so-called 'stereo'. Like the 'anaglyphs', the images that had to be viewed wearing glasses with red and blue glasses to capture the sensation of three-dimensionality invented a few decades earlier by Wilhelm Rollman [Dotto,Vinci 2009, pp. I4, I5], Ader's technique exploited the acquisitions of the most modern human physiology to virtually arouse the sensation of reality. During the exhibition, the spectators crowded the listening room of the Palazzo and followed the work wearing some acoustic devices hung on the wall (fig. 2), a completely new, intimate, personal way that, even within a crowded room, favored the isolation of each auditor. In a newspaper of the time, it was commented: "as soon as you brought the two telephone receivers to your ears, it seemed that suddenly we were transported to the stage

Fig. 2. The Théâtrophone listening room at the Paris, from Le Magasin pittoresque, I882, p. 93.

Fig. 3. Public set for the Théâtrophone, from D. L. Montillot, Le téléphone pratique, Paris, A. Grelot, 1893, p. 465.

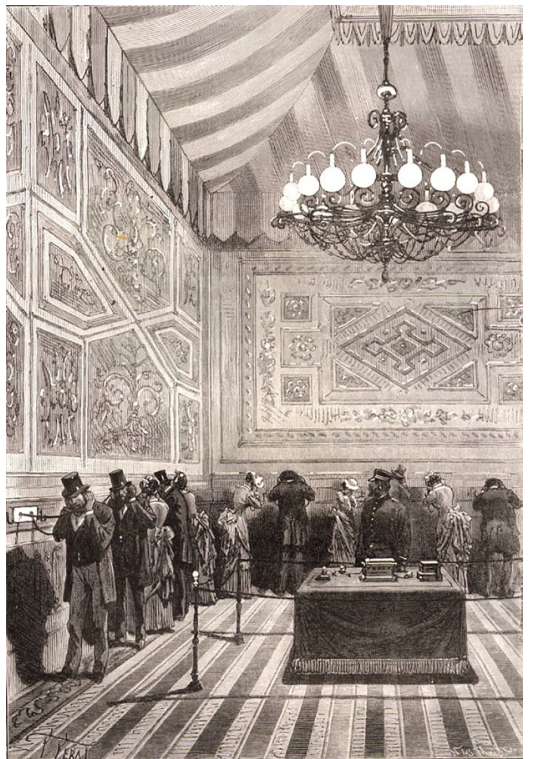

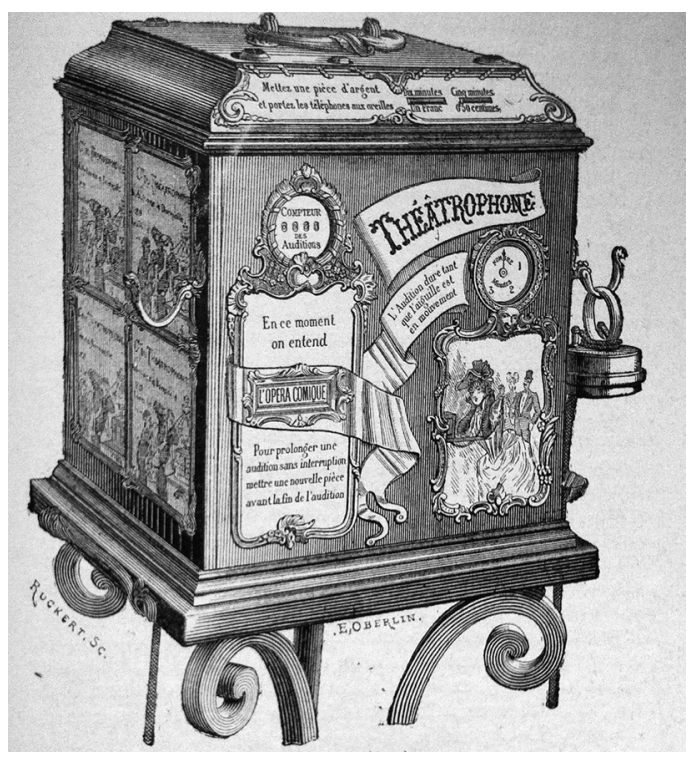


of the Opéra. Closing our eyes, the illusion was complete, we thought we were witnessing the performance itself, hearing Lasalle or the illustrious Krauss singing, listening to the orchestral chords and applause of the audience" [Van Drie 2015, p. 19]. Ader's invention did not have any immediate commercial success but a few years later, at the Universal Exhibition in Paris in 1889, a portable model (fig. 3) of the Théâtrophone was presented which allowed it to be distributed in dedicated listening rooms and even in private homes (fig. 4). From I 890 onwards, subscriptions to the service were offered to users, which allowed a choice between various concerts, operas and other kinds of performances. Daily programs were spread and from 1893 the devices used at the |88| Exposition were installed in a room of the Grevin Museum where users could even listen to variety shows. The Théâtrophone became a means of entertainment that was fully integrated with the uninterrupted flow of Parisian evenings, from those in society to the more intimate and reserved ones and paved the way for new ways of enjoying music and entertainment that went on to conquer more and more, until in 1936, following the evolution of phonographs and the spread of radio, the company that managed the service, already in trouble for some years, withdrew from the business.

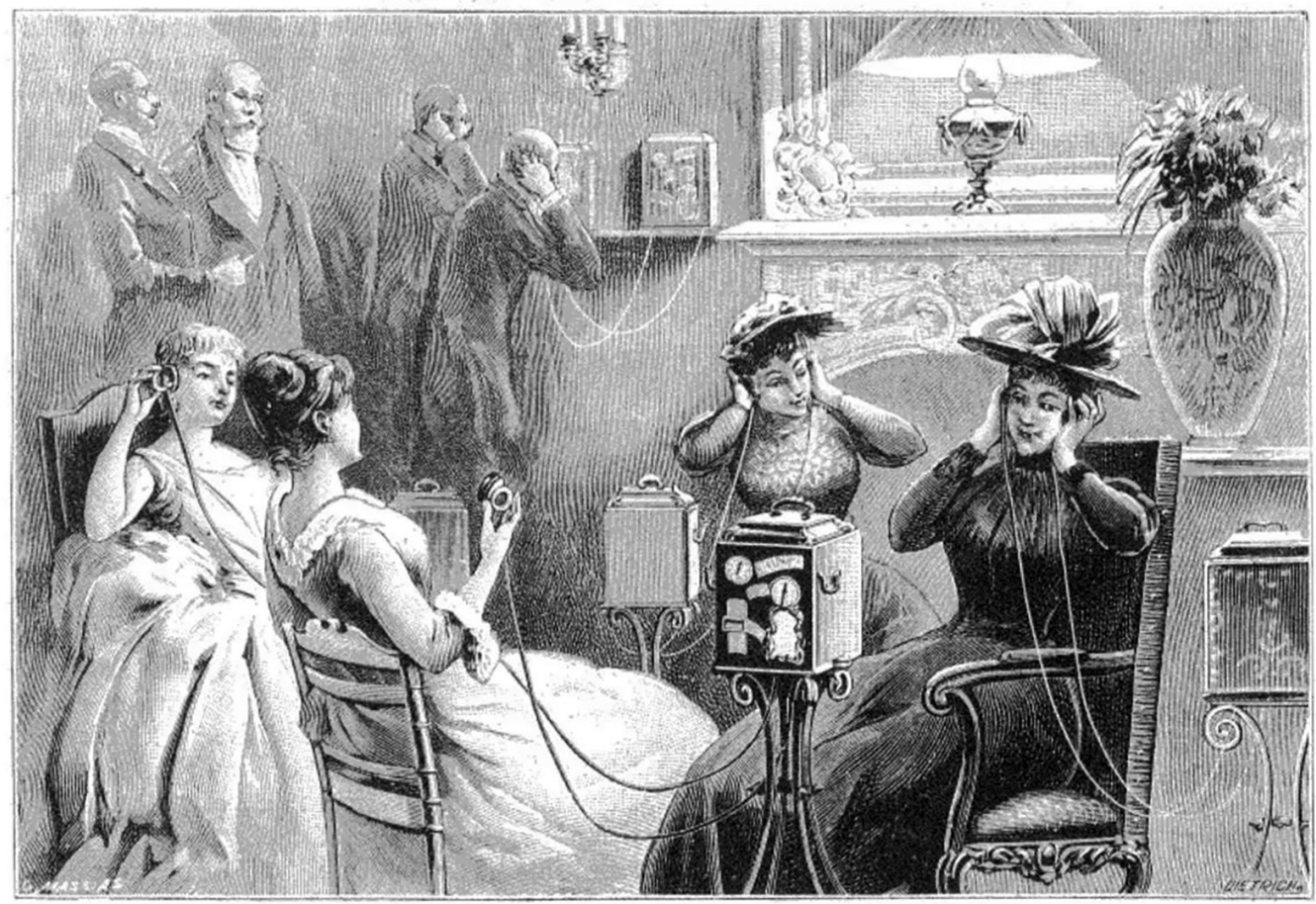

\section{Marcel Proust and the telephone}

Among the subscribers to the Théâtrophone service, from $191 \mid$ onwards, was also Marcel Proust. In that year the writer turned forty and was deeply immersed in the writing of his most famous work, the Recherche, which would be published starting in 1913. As is known, Proust did not like to leave home, also because of his poor health and his confidential nature. The Théatrophone was for him a way to keep up to date with the shows of the city and to 'keep company' during long work sessions. The use of telephone technologies -and the bewilderment they could generate- is the subject of intense reflection included in the 
third volume of his work, Le côté de Guermantes, published in 1921, in which the protagonist of the novel, who is usually identified with Proust himself, about twenty years old -therefore at the beginning of the I890s- he goes to the small town of Doncières to visit a close friend who carries out his military service there. During his stay he finds himself communicating, as well as by letter, also by telephone with his beloved maternal grandmother who constituted an essential emotional reference for him. To be able to make the phone call, he must go to the post office, where he awaits the telephone appointment. The length of waiting irritates him, despite the fact that that meeting may make him enjoy -writes Proust- the "l'admirable féerie à laquelle quelques instants suffisent pour qu'apparaisse près de nous, invisible mais présent, l'être à qui nous voulions parler, et qui restant à sa table, dans la ville qu'il habite (pour ma grand'mère c'était Paris), sous un ciel différent du nôtre, par un temps qui n'est pas forcément le même, au milieu de circonstances et de préoccupations que nous ignorons et que cet être va nous dire, se trouve tout à coup transporté à des centaines de lieues (lui et toute l'ambiance où il reste plongé) près de notre oreille, au moment où notre caprice l'a ordonné", such -Proust continues later- to make us seem "nous sommes comme le personnage du conte à qui une magicienne, sur le souhait qu'il en exprime, fait apparaitre dans une clarté surnaturelle sa grand'mère ou sa fiancée, en train de feuilleter un livre, de verser des larmes, de cueillir des fleurs, tout près du spectateur et pourtant très loin, à l'endroit même où elle se trouve réellement" [Proust 1921, pp. 162, I63]. Proust feels and suffers the emotional burden of this oxymoron, of the disturbing simultaneity of distance and proximity, separation and presence. The voice of the relative heard in Doncières is -tragically and literally- 'out of place'. This awareness constitutes a reason for confusion, bewilderment, sadness and even becomes the omen, rather than of a future rapprochement, of an eternal separation. The weight of the unbridgeable distance between the two interlocutors leads the protagonist - Marcel- to escape from Doncières, to quickly return to Paris to see his grandmother. The familiar voice of the relative, heard a thousand times, continues Proust "mais sa voix ellemême, je l'écoutais aujourd'hui pour la première fois. Et parce que cette voix m'apparaissait changée dans ses proportions dès l'instant qu'elle était un tout, et m'arrivait ainsi seule et sans l'accompagnement des traits de la figure, je découvris combien cette voix était douce" [Proust 1921, p. 164].

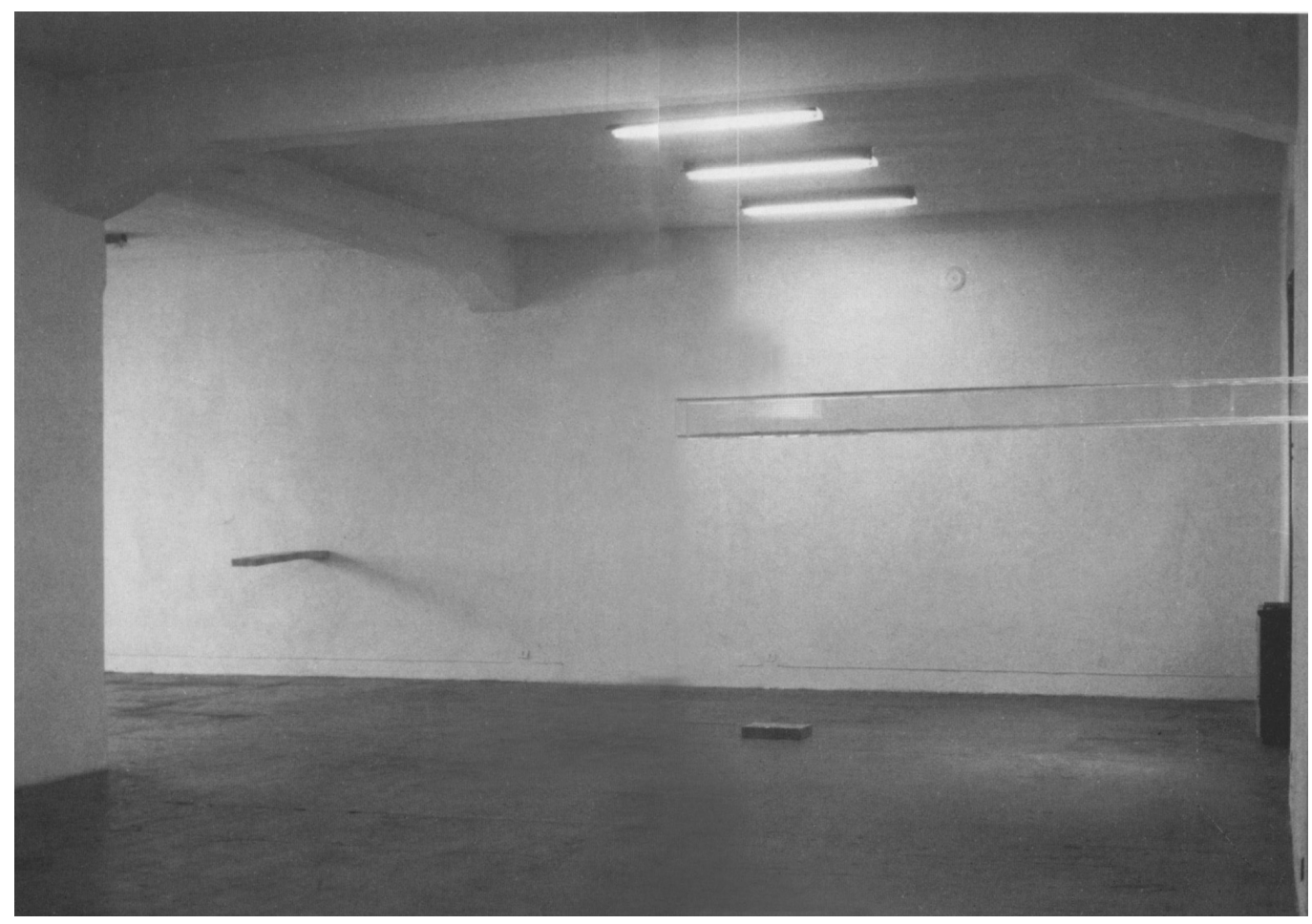




\section{Out of place}

The young Marcel who as a boy struggles in these distressing reflections is not the same as the one who as a mature adult casually uses the means of communication at his disposal and who uses the Théâtrophone to virtually bring his presence outside the walls of the house. On the other hand, he himself notes how "Et pourtant l'habitude met si peu de temps à dépouiller de leur mystère les forces sacrées avec lesquelles nous sommes en contact" [Proust 1921, p. 162]. Its bewilderment easily changes into habit, amazement tends to be absorbed by continuity and -as we all experience daily- after an initial disarray, these technologies generally become effective substitutes for our physical presence. Probably this initial confusion depends on the fact that we tend to frame our experiences in relation to the specific place in which they occur. To remain in the field of experiences related to the use of hearing, it is useful to consider a work by Giuseppe Penone made in the late 1960s [Penone 1977, pp. 56, 59]. The artist builds a refined device capable of generating a subtle form of bewilderment. Inside a room, using a small plexiglass duct connected to the window (fig. 5), he is able to bring the sounds that would have been heard coming from outside, if the window had been opened, to the center of the room. Those sounds are familiar to us, as is the environment in which we find ourselves (a completely ordinary room) and yet in a subtle, punctual and profound way we experience a disturbance due to the fact that the sounds we hear are distant from where they should be, outside their place of choice. In the same way as the voice of the grandmother in Doncières or the faces of our work colleagues that stand out in the intimacy of our room during a video conference, the upheaval built by Penone is a source of a state of surprise.

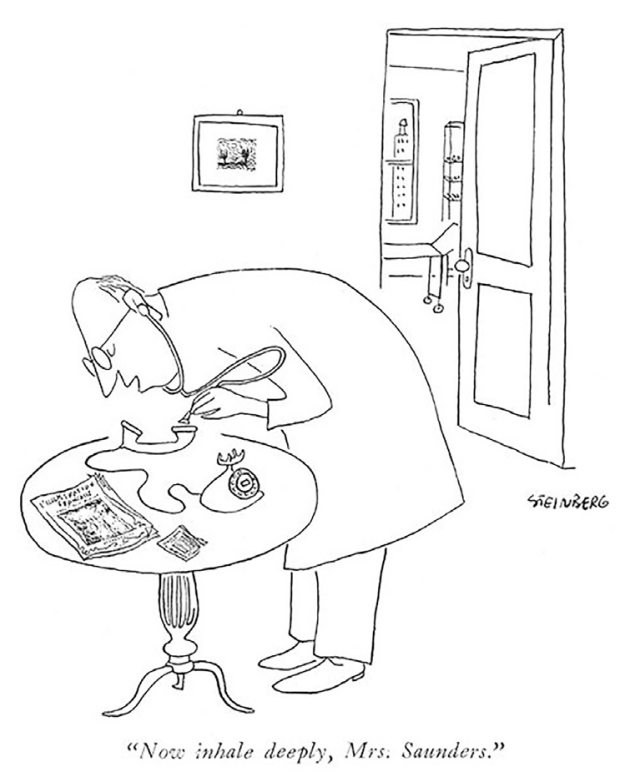

\section{Conclusions}

A cartoon by Saul Steinberg from the 1940s (fig. 6), when modern telemedicine was still an inaccessible frontier, ironically insinuated the possibility that the usual tools of communication could already then open up new possibilities [Steinberg 1945]. After all, on closer inspection, we use these technologies to access distant places exactly as if we were using tools, prostheses, temporary extensions of our body, whose size, whose fleeting borders extend plastically, often without being full of them. awareness. Gregory Bateson clarifies this with a particularly effective example: "Suppose I am a blind man, and I use a stick. I go 
tap, tap, tap. Where do I start? Is my mental system bounded at the handle of the stick? Is it bounded by my skin? Does it start halfway up the stick? Does it start at the tip of the stick? All of these are nonsense questions. The stick is like a channel along which transformations of differences are transmitted" [Bateson 1976, p. 500]. Likewise in our connections, telephone, videoconferencing or otherwise, we extend our presence, temporarily. As Bateson adds - "when the blind man sits down to eat, his stick and his messages will no longer be relevant"- when we turn off the computer we return, at least temporarily, to a different bodily dimension, closer to that defined by the boundaries of our own form. The devices mentioned above, if viewed from the point of view focused by Bateson, are fully connoted as tools, capable of putting us in contact with distant places. This communication takes place through specific channels -the tactile one for Bateson's stick or the auditory one for the Théattrophone- each of which constitutes an apodictic synthesis of the reality with which we interact, the same functional synthesis that substantiates every form of representation whose effectiveness only unravels thanks to the choice and use of strictly essential information. The modalities that belong to the two examples quickly considered in these pages, the Théâtrophone and the telephone, despite the enormous differences with the complex visual modalities -certainly more suited to our times and more in keeping with our study interests- entertain with them enormous analogies and seem to deeply share the key concepts to refer to, that of instrument and that of representation.

\section{References}

Bateson G. (1976). Verso un'ecologia della mente. Milano:Adelphi. [ed. origin. Steps to an Ecology of Mind, San Francisco: Chandler Publishing Company, 1972].

Dotto E., Vinci F. (2009). Gli anaglifi geometrici. Storia e costruzione grafica. Siracusa: Lombardi.

Maldonado T. (1992). Reale e virtuale. Milano: Feltrinelli.

Penone G. (1977). Rovesciare gli occhi. Torino: Einaudi.

Pisano G. (2012). The Théâtrophone, an Anachronistic Hybrid Experiment or One of the First Immobile Traveler Devices? In: A. Gaudreault, N. Dulac, S. Hidalgo (a cura di). A Companion to Early Cinema, pp. 80-98. Pasig:Wiley and sons -Blackwell Pub.

Proust M. (1995). Alla ricerca del tempo perduto - III. La parte di Guermantes. Milano: Mondadori. [ed. origin. Le Côté de Guermantes. Paris: Gallimard, 1921 ]

Sakamoto H. (2006). Du théâtrophone au téléphone repenser la «mise en scène» du dialogue dans «à la recherche du temps perdu". In R. Goedendorp et al. (Eds.). Marcel Proust Aujourd'hui, vol. 4, Proust et le théâtre, pp. 25I-27I.

Steinberg S. (1945). All in line. New York: Penguin Book.

Van Drie M. (20 I5). L'espace scénique du théâtrophone (I 88 I - 1930) et la figure nouvelle du spectateur auditeur. In Modèles et modalités de la transmission Culturelle, pp. 4 I-68. Paris: Éditions de la Sorbonne.

Van Drie M. (2016). Hearing through the théâtrophone: Sonically constructed spaces and embodied listening in the late nineteenth-century French theatre. In SoundEffects - An Interdisciplinary Journal of Sound and Sound Experience, 5( I), pp. 73-90.

\footnotetext{
Author

Edoardo Dotto, Università di Catania, edoardo.dotto@unict.it

To cite this chapter: Dotto Edoardo (202I). Fuori luogo. Contatti uditivi tra Ottocento e Novecento/Out of place. Auditory contacts between the nineteenth and twentieth centuries. In Arena A., Arena M., Mediati D., Raffa P. (a cura di). Connettere. Un disegno per annodare e tessere. Linguaggi Distanze Tecnologie. Atti del $42^{\circ}$ Convegno Internazionale dei Docenti delle Discipline della Rappresentazione/Connecting. Drawing for weaving relationship. Languages Distances Technologies. Proceedings of the $42^{\text {th }}$ International Conference of Representation Disciplines Teachers. Milano: FrancoAngeli, pp. $|60|-16 \mid 4$.
} 